\title{
Is the CFA Franc Prone to Speculative Attacks or a Contagion Effect: A Stochastic-Markov Transition Analysis for Cameroon
}

\section{Louis S. Nkwatoh ${ }^{1}$ and Kwanga Cornelius ${ }^{2}$}

The study employs the Markovian processs on annual nominal effective exchange rate of CFA Franc spanning 1975 to 2017 to examine whether the CFA franc is prone to speculative attacks or a contagion effect. The findings reveal that the expected duration for the CFA Franc to be undervalued is twice higher than for it to be overvalued. This validates the contagion effect of a Euro crisis on the CFA Franc. Though the level of growth increased significantly during the undervaluation era, the level of uncertainty remains equally high. The findings confirm that exchange rate devaluation influences the expectations of private agents, which in turn triggers an attack on the domestic currency.

Keywords: Contagion Effect, Exchange Rate, Overvaluation, Undervaluation, Speculative Attacks, Stochastic-Markov Process

JEL Classification: C58,D84,G01, G17.

DOI: 10.33429/Cjas.10119.5/6

\subsection{Introduction}

Creating a common economic space as a result of increasing cross-border trade has motivated the use of a common currency by members of the same regional bloc. This process is feasible only to countries bonded by specific regional activities that are willing to surrender their monetary policy sovereignty and adopt the fixed exchange rate as a tool for macroeconomic stability.

Even though the fixed exchange rate is viewed as a mechanism that automatically adjusts the balance of payments, avoids currency fluctuations, maintains price stability and encourages investment across member countries in a currency union, Labonte (2004) however, submits that the fixed exchange rate system actually limits the ability to pursue expansionary monetary policies thereby exposing

\footnotetext{
${ }^{1}$ Corresponding Author: Department of Economics, Usmanu Danfodiyo University, Sokoto. Email: sevinkwatoh@gmail.com, Tel: +2348062218765

${ }^{2}$ Department of Economics, Umaru Musa Yar,Adua University Katsina
} 
economies to external shocks. Another major weakness is that the fixed exchange rate can trigger a currency crisis accompanied by a series ofspeculative attacks in the foreign exchange rate market if the union's central bank does not have sufficient foreign exchange reserves to maintain the fixed exchange rate (Al-Assaf et al., 2013).

In mid-November 2011, rumours about a possible devaluation of the African Financial Community (CFA) Franc due to the Euro zone crisis triggered speculations among economic agents. Remarkably, this encouraged huge capital flight that led to financial leakages as was the case immediately before the devaluation exercise in 1994 (see, Forgha, 2008; Dembele, 2014). Also, the CFA franc has been pegged to the Euro implying that in the wake of a Euro crisis, the symptoms are likely to manifest in the Franc zone (contagion effect). The twin effect raises uncertainties within the different sectors of the economy and can undermine policy effectiveness.

The main objective of the study is to examine whether the CFA franc is prone to speculative attacks or a contagion effect by modelling the fixed exchange rate for Cameroon. This study departs from the traditional linear approach of analysing the dynamics of fixed exchange rate in most studies in the Economic Community of Central African States (CEMAC) zone to a non-linear modelling approach (Markovian process) which is a novelty. This approach is justified because the fixed exchange rate has undergone a policy shift from the overvaluation era (1945 - 1993) to the undervaluation period (1994 to date). According to Obstfeld (1996), shifts in policy regimes are characterised by heterogeneous behaviours of macroeconomic variables that produce multiple equilibria. In this regard, policy shifts in the CEMAC zone suggest that the fixed exchange rate displays multiple equilibria and thus exhibits non-linear properties.

The rest of the paper is structured as follows: Section 2 provides the theoretical/empirical discourse. Section 3 contains the methodology while Section 4 presents the analysis and results. The conclusion is contained in Section 5. 


\subsection{Literature Review}

\subsection{Theoretical Framework}

Countries in an optimum currency area use the fixed exchange rate regime as a tool to stabilise macroeconomic activities. However, currency crises are inevitable in a fixed exchange rate regime; and this has prompted researches on the exact causes of the crises, their consequences and how they can be circumvented.

Most Economists concur that investors' sentiments generate speculative attacks, especially when the future value of money is not certain. Making allusion to the gold market, Salant and Henderson (1978) argue on theoretical grounds that the drawbacks in stabilizing the unpredictable prices of official gold stocks will expose the market to devastating speculative attacks. According to Krugman (1979), speculative attacks on the fixed exchange rate can result from the rational behaviour of investors.

Uncertainty and unpredictability of the value of a currency weaken both its effectiveness as a medium of exchange and the envisaged success of the fixed exchange rate regime. Labonte (2004) opines that the weakness of the fixed exchange rate regime occurs when macroeconomic fundamentals change in such a way that devaluation becomes necessary. Krugman (1979) observes that the weak macroeconomic fundamentals provide a platform for attacks under the fixed exchange rate regime because government deficit financing using foreign reserves negatively affects a currency regime. An extension of Krugman's model by Flood and Garber (1984) indicates that the collapse of the fixed exchange rate regime is random, unlike Kugman's model which suggests that there is prior information before the collapse of the regime.

An alternative view, which nevertheless, complements Krugman's model is the self-fulfilling prophecy put forth by (Obstfeld, 1996). The main thrust of this view is that, investors' pessimism about the future triggers currency crises rather than weak macroeconomic fundamentals. Obstfeld argues that expectations of devaluation by investors lead to actions that raise the opportunity cost of defending 
the existing fixed parity and therefore, force policy response to validate investors' expectations. In the same vein, Dellas and Stockman (1993) argue that expectations of capital control and devaluation precipitate a currency crisis, even when the fundamentals of the economy are strong. Similarly, Morris and Shin (1998) opine that information on macroeconomic fundamentals is not a common knowledge. According to these authors, information itself is heterogeneous and speculators are uncertain about what other speculators will do. On this basis, the self-fulfilling prophecy is characterised by multiple equilibria, implying that the fixed exchange rate exhibits non-linear properties and therefore, follows a Markovian process.

A synopsis of the two views shows that shifts in investors' perception precipitate currency crises. However, the factors that trigger shifts in private agents' expectations are yet to be explained. This submission is crucial and forms the premise for further discussions. McKinnon and Pill (1996), Krugman (1998), and Corsetti et al. (1998) suggest that vulnerabilities stemming from over-borrowing can trigger currency crises. That is, a situation where banks suffer a sudden withdrawal of deposits (bank run) due to over-borrowing and find it difficult to recover such funds thereby, rendering them insolvent. This phenomenon is commonly tagged banking panic. Radelet and Sachs (1998) submit that self-fulfilling panics will force the liquidation of assets leading to currency crises. Chang and Velasco (2000) assert that currency crisis may cause a banking crisis if domestic banks have debts denominated in foreign currency. Likewise, Burnside et al. (2001 and 2004) purport that a government guarantee of the banking system may give banks the incentive to form markets, making both the currency and the banking system vulnerable to speculative attack.

The interactions between a banking system and currency crisis can also generate a twin crisis. McKinnon and Pill $(1996,1998)$ submit that financial liberalization and deposit insurance may fuel a lending boom which in turn expands both foreign and domestic credit thereby leading to a banking and currency crisis. The twin crisis has been justified in the works of Chang and Velasco (1999); Kaminsky and Reinhart (1999); Reinhart and Vegh (1995) among other authors. Contrary views show that banking crisis causes currency crisis. For instance, Obstfeld (1994) 
argues that a weak banking sector may precipitate a currency crisis if policymakers choose inflation over exchange rate stability to avoid bankruptcies. Likewise, Gonzalez-Hermosillo (1996) demonstrates that a banking crisis may lead to a currency crisis in a poorly developed financial system when agents decide to substitute foreign assets for domestic assets. Alternative views also suggest that currency crises induce banking crisis. Miller (1996), for example, shows that speculative attacks on local currency will lead to banking crisis, especially when depositors' funds are used for speculation in the foreign exchange market and banks are loaned up.

A more recent debate shows that an economic turmoil in a country can be transmitted to other countries if they are bonded by a specific activity. In other words, financial contagion occurs when negative market shocks are transmitted from one country or region to the other (Osadume \& Mbachu, 2017), through co-movements in exchange rates, stock prices, sovereign spreads, and capital flows (Dornbusch et al.2000). Initially, the concept of contagion became topical and relevant in economics, after the devaluation of Thailand's Thai baht in 1999 that generated a wave of financial crises that resonated to some Asian countries. But in recent times, Helleiner (2011) submits that the financial crisis of 2007-2008 that threatened major financial institutions around the World remains the most severe since the 1930 Great Depression. For instance, the busting of the housing bubble in the United States and the increase in mortgage defaults rapidly developed and spread into a global economic shock, resulting in a number of European bank failures, declines in various stock indexes, and large reductions in the market value of equities(Norris, 2008) and commodities (Ambrose, 2007). This crisis contributed to the European sovereign-debt crisis and a downturn in economic activities leading to the Global Recession between 2008 and 2012 (Osadume \& Mbachu, 2017). The symptoms of the Euro debt crisis are likely to manifest in the Franc zone simply because the CFA franc is pegged to the Euro, a phenomenon commonly known as the contagion effect. 


\subsection{Empirical Literature}

The assessment of exchange rate dynamics is centred on the desired exchange rate equilibrium that will either guarantee stability or the degree of misalignment that will undermine macroeconomic stability. A broad spectrum of the literature focuses more on these two phenomena probably because the occurrence of multiple equilibria questions the appropriateness and effectiveness of the fixed exchange rate as a stabilizing policy. Examples of such studies are Devarajan and Hinkle (1994), Kiguel and Ghei (1993), Linjouom (2009) among others Baffes, Elbadawi, and O'Connell (1999), Tassa, Yamb and Kouezo (2002), Traoré (2004) Linjouom (2009), Gnansounouand and Verdier-Chouchane (2012), Abdih and Tsangarides (2006) among others. All these studies have modelled the fixed exchange rate in the CEMAC regions as a linear process, whereas the fixed exchange rate exhibits multiple equilibria and requires a non-linear approach. According to Fratzscher (2002), an important shortcoming of linear function estimations is that it undermines the possibility that shifts in expectations and private sector beliefs which might also cause crises.

The use of Markov chains in modelling non-linear series to describe regime switching patterns was first introduced by Quandt (1958) because of its clarity in understanding regime switching behaviours of macroeconomic and financial time series and modelling of non-linear time series. For instance, Engel and Hamilton (1990) showes that exchange rates follow a Markovian process and that the dollar, forexample, exhibits recurrent long swings with periods of persistent appreciation and depreciation indicating an infrequent switch between the different regimes. In another related study, Engel (1993) confirms the superiority of the Markov model in predicting the direction of change of the dollar exchange rate by making use of the mean-squared-error criterion. Shen and Chen (2002), in line with the above authors, reached the same conclusion for Japan stating clearly that the random walk remains unsatisfactory from an economic standpoint because it ignores the impact of economic fundamentals. However, Cheung and Erlandsson (2004) remain indifferent to the forecasting power of the competing models because neither the random walk nor Markov-switching is crucial for determining the number of regime shifts of the dollar exchange rate within their chosen sample study. 
Literature also has it that Markov-switching models better forecast early warning signs of currency crises other than the threshold used by (Kaminsky \& Reinhart, 1999; Goldstein et al.,2000) who claims that the threshold succeeded in predicting the Asian crisis. However, Vargas (2009) using the Asian Financial Crisis as an example illustrated that the Markov-Switching VAR model with time-varying transition probabilities signals currency crises better than threshold models. Markovian models that signal currency crises are recorded in the works of (Fratzscher, 1999; Heriqbaldi, 2009; Cerra \& Saxena, 2002; Martinez \& Peria, 2002).

Markov-Switching models are suitable for modelling exchange rate behaviours with recurrent shifts due to market fundamentals. Bazdresch and Werner (2005)employed the regime switching techniques to examine appreciation and depreciation episodes of the nominal exchange rate of the Mexican Peso. Ifeoma et al.(2013) showed that the appreciation and depreciation of the Nigerian Naira via dollar rate would be stable in the long run. Alvarez-plata and Schrooten (2006) established that shifts in agents' beliefs did play a crucial role in the currency crises from 1995 to 2002 in Argentina.

The use of Markov-Switching models to predict the behaviour of exchange rate dynamics is justified empirically in the work of Chen (2006). Goutte and Zou (2011) employed the Cox (1985) model, which is a modified form of the Hamilton's (1989) Markov-type regime switching framework, to show that the exchange rates of various currencies: Euros, Dollars, Yuan, Yen and the Livre react faster to financial crisis. Their data set covered monthly data from 2010 to 2011 . Tsaur (2012) used a fuzzy logic time series for small samples of exchange rate to derive a Markov chain transition matrix and to obtain a set of adjusted enrolment forecasting values. The finding of this study reveals that the Markov model was effective in forecasting exchange rate movements between the Taiwan and the US Dollar.

Engel (1994) modelled regime shifts in exchange rates to accertain nature of its predictability. Using multiple regime switching models, the author shows that the Markov model predicts exchange rate movements in China better than other 
regime switching models. Extending the work of Engel (1994), Nikolsko and Prodan (2014) provide evidence of both short-horizon and long-horizon predictability of the pure statistical modelafter applyingMS-RW model over a larger dataset of currencies of 12 OECD countries versus the dollar.

Shafiquddin (2016) examined the validity of a (modified) exchange rate model between monthly Bangladeshi Taka and Indian Rupee exchange rate in a MarkovSwitching framework. Using monthly data from May 2003 to March 2016, the results lend support to the Markov-Switching model in capturing long swings in the observed exchange rate. Further results reveal that various monetary fundamentals (i.e., interest rate differential, inflation rate differential, money growth differential, and trade balance) are significant determinants of the Taka-Rupee exchange rates.

A plethora of literature shows that a financial crisis can be contagious to foreign banks and stock markets. Sosa and Ortiz (2016) using symmetric and asymmetric GARCH models confirmed the presence of an asymmetric volatility in the North Financial Trade Agreement (NFTA) equity markets, resulting from the contagion effect of the global financial crisis. Park \& Shin (2017) tested the contagion effectof the global financial crisis on emerging market economies using descriptive statistics. Their findings showed that emerging market economies suffered more capital outflows during the global financial crisis.

\subsection{Methodology}

This study used the Markov Chain which is a stochastic process developed by a Russian mathematician AndreiMarkov in 1906 with the basic assumption that there is a one-stage dependence of events, with each event depending instantaneously on the preceding event. Hamilton (1989) and Engel and Hamilton (1990) introduced the Markov-Switching Autoregressive (MS-AR) model to explain regime switching behaviours of time series variables. If a variable switches between $\mathrm{N}$ different regimes or state spaces $S_{r}\left(r=1\right.$ and2) then $S_{r}$ becomes random and assumes integer values: $0 \leqslant S_{r} \leqslant N$. The choice of the MS-AR is 
predicated on its predictive power of non-linear time series variable (see, Abiad, 2003; Gultekin et al., 2003; Brunetti et al. 2008). Lee and Chen (2007) justified the use of Markov-Switching models because of its consistency with most popular exchange rate regimes in the world.

Cameroon has experienced two policy regimes under the fixed exchange rate system, which requires a 2 -state Markov chain such that $S_{r}=1$, for regime one (overvaluation regime) and $S_{r}=1$ for regime two (undervaluation regime). Thus, the Hamilton's 2-state MarkovSwitching Autoregressive Model of order q (MS (2)-AR (q)) is such that:

$$
y_{t}=\mu / S_{r}+\left[\left(S_{r}\right) \sum_{i=0}^{q} \beta_{i} y_{t-i}-\mu\left(S_{r}\right)\right]+\varepsilon_{t}
$$

$\mu_{t} \sim N I D\left(0, \sum\left(S_{t}\right)\right)$ and $S_{r}=$ state 1 and $2(r=1$ and 2$)$.

$\mu / S_{t}$ is the conditional mean, $\beta_{i}$ is the coefficient of the lagged values of the variable in different regimes, and $S_{r}$ is the variance in each regime. The vector parameter, $\beta$, is assumed to be constant (does not switch in a Markov process).

Switching between N-states is an ergodic Markov chain that is captured by transition probabilities $\left(P_{i j}^{n}\right)$ derived from the Chapman-Kolmogorov's equation. $\left(P_{i j}^{n}\right)$ is the probability of switching from previous state $\mathrm{i}$ at period $t-1\left(S_{t-1}\right)$ if it occurred to a current state, $j$, at period $t\left(S_{t}\right)$ after n periods:

$P\left\{S_{r}=j / S_{r-1}=i, S_{r-2}=k, \ldots\right\}=P\left\{S_{r}=j / S_{r-1}=i\right\}=P_{i j} \sum_{j=1}^{m} P_{i j}=1, \forall i j \in$ $\{1,2,3, \ldots, M\}$ and $0 \leqslant P_{i j} \leqslant 1$

Thus, $S_{t}$ follows a Markov process, with transition probability matrix, $P^{*}$ as follows:

$$
P^{*}=\left(\begin{array}{cccc}
P_{11} & P_{12} & \ldots & P_{1 M} \\
P_{21} & P_{22} & \ldots & P_{2 M} \\
\cdot & \cdot & \cdot & \cdot \\
\cdot & \cdot & \cdot & \cdot \\
\cdot & \cdot & \cdot & \cdot \\
P_{M 1} & P_{M 2} & \ldots & P_{M M}
\end{array}\right)
$$

where $P_{11}+P_{12}, \ldots, P_{1 M}=1$. 
The expected time spent in the different states can be calculated from the transition matrix. For a 2-state Markov process, the expected duration of the overvaluation regime is: $\left(1-P_{11}\right)^{-1}$, while the expected duration of the undervaluation regime is: $\left(1-P_{22}\right)^{-1}$. Thus, the estimated MA (2)-AR (2) exchange rate model for this study is:

$$
\log N F E X_{t}=\mu / S_{r}+G D P G R+\left[\left(S_{r}\right) \sum_{i=0}^{q} \beta_{i} N F E X_{t-1}-\mu\left(S_{r}\right)\right]+\varepsilon_{t}
$$

The GDPGR in equation 2 captures the behaviour of economic growth rate in the two regimes and NFEX is the nominal fixed exchange rate. The introduction of AR terms in the model is imperative because most time series variables induce autocorrelated errors and fail in the specification tests (Chen \& Shen, 2009). Therefore, lagging the dependent variables on the right-hand side solves the problem of autocorrelation. Secondly, the AR terms captures the inertia factor which provides vital information on the expectations of economic agents on the conditions of the domestic economy.

The estimates of the regime probabilities may be improved by using all of the information in the sample. The smoothed estimates for the regime probabilities in period, $t$, use the information set in the final period, $N_{t}$ (see, Eviews 9 User Guide II, page 447, 2015 IHS Global Inc). A summary of Kim (2004) algorithm leads to an efficient smoothing of the probabilities of the form:

$$
P\left(S_{t}=i / N_{t}\right)=\sum_{j=1}^{M} P\left(S_{t}=i, S_{t+1}=j / N_{t}\right)
$$

All other terms are obtained through filtering, except for the smooth probability term $\left(S_{t+1}=j / N_{t}\right)$

\section{Sources of Data}

Annual data for GDP growth rate was obtained from the World Development Indicators website, while nominal effective exchange rate was extracted from EconStats and Ceicdata websites respectively.The data covered the period 1975 to 2017 to fully accommodate the two policy regimes under the fixed exchange rate system. The variables considered for the two regimes are nominal exchange rate (NEER) 
and growth rate of real gross domestic product (GDPGR).

\subsection{Presentation and Analysis of Results}

Time series data often times are not stationary and therefore causes spurious regression. In this regard, the study employed the Elliot-Rothenberg-Stock DFGLS $^{3}$ proposed by Elliot et al. (1996) to determine the order of integration of the series. The DF-GLSisan augmented Dickey-Fullerbasedtest, which begins by transforming the time series through a generalized least squares (GLS) regression before performing the test. Elliott et al. (1996) showed that the DF-GLS has significant greater power over the previous versions of the augmented Dickey-Fuller test. The results in Table 1shows that the NEER is stationary at level, while GDPGR series is integrated of order one $I(1)$, i.e., stationary after first difference.

Table 1: Unit Root Tests at Levels and First Difference of LOGNEER and

GDPGR

\begin{tabular}{lccc}
\hline \multicolumn{4}{c}{ Elliott-Rothenberg-Stock DF-GLS Test Statistic } \\
Constant Linear Trend (Lag Length: 1 (Fixed)): Test Critical Values & $1 \%=1.8760 ;$ & $5 \%=2.9700 ; 10 \%$ \\
Series & Levels & First Difference & Order of Integration \\
\hline NEER & 7.83040 & - & $\mathrm{I}(0)$ \\
GDPGR & 2.76260 & 4.39560 & $\mathrm{I}(1)$ \\
\hline
\end{tabular}

\subsection{Regime Selection Criteria}

Figures 1, 2 and 3 show the selection criteria for the different estimated MSAR models. The robustness of the estimated model was judged based on the nature of their autocorrelation functions (ACF), partial autocorrelation functions $(\mathrm{PACF})$ and the value of the Q-statistic at the highest lag of the correlogram. The correlogram in Figure 1 shows that the terms (spikes) of the ACF and PACF lie within the band confidence interval significantly equal to zero at 5 percent. Furthermore, the Q-statistic at lag 15, has a probability value of 0.866 greater than 0.05 critical value, implying that MS (2)-AR(1) is more robust.

\footnotetext{
${ }^{3}$ When the series has been suitably de-trended, the DF-GLS follows a similar procedure as the traditional ADF test, i.e., the null of a unit root $\left(H_{0}: \alpha^{*}=0\right)$ can be tested in: $\Delta y_{t}^{d}=\alpha^{*} y_{t-1}^{d}+\sum_{j=1}^{p-1} \beta \Delta y_{t-j}^{d}+\varepsilon_{t}$
} 


\begin{tabular}{|c|c|c|c|c|c|c|c|c|}
\hline \multicolumn{2}{|c|}{ Autocorrelation } & \multicolumn{3}{|c|}{ Partial Correlation } & \multirow{2}{*}{$\begin{array}{l}\mathrm{AC} \\
0.125\end{array}$} & \multirow{2}{*}{$\begin{array}{l}\text { PAC } \\
0.125\end{array}$} & \multirow{2}{*}{$\begin{array}{l}\text { Q-Stat } \\
0.6898\end{array}$} & \multirow{2}{*}{$\begin{array}{l}\text { Prob }^{*} \\
0.406\end{array}$} \\
\hline 1 & 1 & 1 & 1 & 1 & & & & \\
\hline 1 & I & 1 & I & 2 & 0.098 & 0.083 & 1.1224 & 0.571 \\
\hline 1 & I & 1 & I & 3 & 0.103 & 0.084 & 1.6185 & 0.655 \\
\hline & & & ו & 4 & 0.291 & 0.271 & 5.6653 & 0.226 \\
\hline 1 다 & I & $1 \square$ & I & 5 & -0.133 & -0.225 & 6.5311 & 0.258 \\
\hline $1 \mathrm{~d}$ & I & 1 व & $\mathrm{I}$ & 6 & -0.090 & -0.114 & 6.9417 & 0.326 \\
\hline 1 & I & 1 & 1 & 7 & 0.009 & 0.018 & 6.9461 & 0.435 \\
\hline 10 & I & 1 口 & 1 & 8 & -0.107 & -0.172 & 7.5584 & 0.478 \\
\hline 1 다 & I & 1 & I & 9 & -0.120 & 0.033 & 8.3559 & 0.499 \\
\hline 1 & I & 1 & I & 10 & -0.018 & 0.060 & 8.3737 & 0.592 \\
\hline 1 & , & 1 & 1 & 11 & -0.017 & -0.047 & 8.3902 & 0.678 \\
\hline 1 & I & 1 & I & 12 & -0.029 & 0.077 & 8.4397 & 0.750 \\
\hline 1 & I & 1 口 & I & 13 & 0.109 & 0.122 & 9.1844 & 0.759 \\
\hline 1 & I & 1 미 & 1 & 14 & -0.014 & -0.130 & 9.1963 & 0.818 \\
\hline 1 & I & 17 & $\mathbf{I}$ & 15 & -0.020 & -0.011 & 9.2237 & 0.866 \\
\hline
\end{tabular}

*Probabilities may not be valid for this equation specification.

Figure 1: Correlogram of MS (2)-A(1)

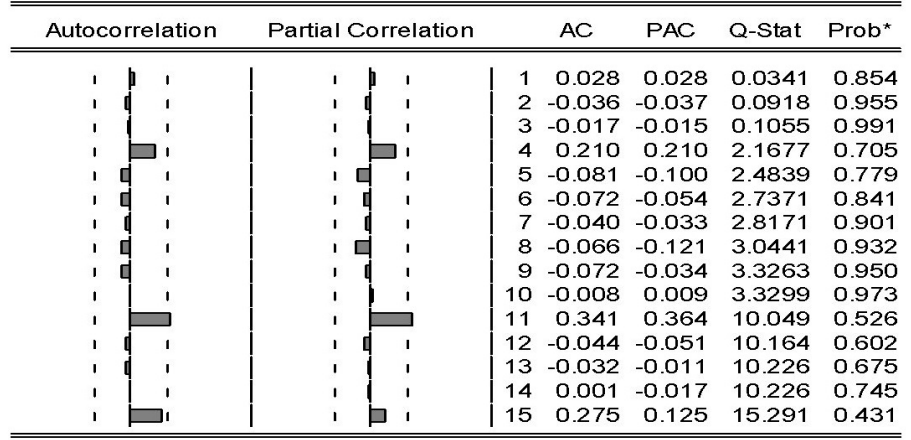

*Probabilities may not be valid for this equation specification

Figure 2: Correlogram of $\mathrm{MS}(2)-\mathrm{AR}(2)$

\begin{tabular}{|c|c|c|c|c|c|c|c|c|}
\hline \multicolumn{2}{|c|}{ Autocorrelation } & \multicolumn{3}{|c|}{ Partial Correlation } & \multirow{2}{*}{$\begin{array}{l}A C \\
0.687\end{array}$} & \multirow{2}{*}{$\begin{array}{l}\text { PAC } \\
0.687\end{array}$} & \multirow{2}{*}{$\begin{array}{l}\text { Q-Stat } \\
19.841\end{array}$} & \multirow{2}{*}{$\begin{array}{l}\text { Prob* }^{*} \\
0.000\end{array}$} \\
\hline 1 & & 1 & & 1 & & & & \\
\hline 1 & $\square$ & $1 \sqsubset$ & 1 & 2 & 0.369 & -0.195 & 25.715 & 0.000 \\
\hline 1 & $\square 1$ & 1 & 1 & 3 & 0.166 & -0.005 & 26.944 & 0.000 \\
\hline & 1 & $1 \square$ & 1 & 4 & -0.037 & -0.197 & 27.008 & 0.000 \\
\hline $1 \square$ & 1 & 17 & 1 & 5 & -0.181 & -0.071 & 28.549 & 0.000 \\
\hline 무 & 1 & 1 & 1 & 6 & -0.190 & 0.049 & 30.303 & 0.000 \\
\hline 문 & 1 & 1 & 1 & 7 & -0.161 & -0.025 & 31.598 & 0.000 \\
\hline 14 & 1 & 1 & 1 & 8 & -0.078 & 0.085 & 31.911 & 0.000 \\
\hline d & 1 & $1 \square$ & 1 & 9 & -0.079 & -0.184 & 32.246 & 0.000 \\
\hline 7 & 1 & 17 & 1 & 10 & -0.035 & 0.110 & 32.312 & 0.000 \\
\hline 1 & I & & 1 & 11 & 0.059 & 0.069 & 32.510 & 0.001 \\
\hline $1 \overline{1}$ & 1 & , ᄃ & 1 & 12 & 0.030 & -0.137 & 32.563 & 0.001 \\
\hline 1 & 1 & $1 \square$ & 1 & 13 & -0.109 & -0.193 & 33.294 & 0.002 \\
\hline 1 प & 1 & $1 F$ & 1 & 14 & -0.086 & 0.162 & 33.764 & 0.002 \\
\hline 14 & 1 & 1 & I & 15 & -0.059 & -0.015 & 33.995 & 0.003 \\
\hline
\end{tabular}

*Probabilities may not be valid for this equation s pecification.

Figure 3: Correlogram of $\operatorname{MS}(2)-\operatorname{AR}(3)$ 
Table 3 shows the estimated results of an MA(2) - AR(1) when the nominal exchange rate is modelled as two states or regimes (overvaluation and undervaluation). The estimated intercept of state one is approximately 2.026, which dropped to approximately 1.998 in state two. This result is justified because the exchange rate was overvalued in the first regime and undervalued in the second regime. Secondly, the GDP growth rate (GDPGR) in state one is negative (-0.0054) and significantly positive (0.0011) in the state two. This is also justified because the economic growth rate was lower in the overvaluation regime and increased significantly in the undervaluation regime immediately after the CFA franc was devalued. Also, the degree of uncertainty is higher in state one $\left(\sigma_{1}=0.27\right)$ than in state two $\left(\sigma_{1}=0.17\right)$.

The autoregressive coefficient is positive, implying that the current value of the exchange rate was strongly influenced by the previous years' exchange rate. In other words, the undervaluation of the CFA franc was prompted by the overvaluation of the domestic currency. Furthermore, the significance of the autoregressive term suggests that the exchange rate in the previous period influenced the expectations of private agents towards the behaviour of the exchange rate in the current period. This implies that private agents' expectations about the CFA franc were motivated by the devaluation exercise.

Table 3: Estimated MS (2) - AR (1) Model

\begin{tabular}{lccc}
\hline Regime Variables & Coefficients & Z-Statistics & $p$-Value \\
\hline C $(1)$ & 2.0260 & 106.2000 & 0.0000 \\
C $(2)$ & 1.9970 & 171.8000 & 0.0000 \\
DGDPGR (1) & -0.0054 & -3.7100 & 0.0002 \\
GDPGR (2) & 0.0011 & 2.0600 & 0.0391 \\
\multicolumn{4}{c}{ Autoregressive Coefficients } \\
AR $(1)$ & 0.7480 & 9.6400 & 0.0000 \\
Log(Sigma $)$ & $-2.7060\left(\sigma_{1}=0.27\right)$ & -9.8700 & 0.0000 \\
Log(sigma $)$ & $-4.449 \quad\left(\sigma_{2}=017\right)$ & -26.2000 & 0.0000 \\
& Transition Matrix \\
& Parameters \\
P_ $\{1 \mid 1\}-C(1)$ & 0.7310 & \\
P_\{2|1\}-C $(2))$ & -1.9900 & 0.9040 & 0.0000 \\
\hline
\end{tabular}




\subsection{Regime Transition Probability}

The matrix on Table 4 shows the probability of moving from one regime to the other. The probability of switching from an overvaluation regime to an undervaluation regime is higher (0.880) and is lower when switching from an undervaluation regime to an overvaluation regime (0.686). Furthermore, the ergodic probabilities show that the average expected duration that Cameroon's domestic currency can be overvalued is approximately 3 quarters and the average expected duration for the currency to be undervalued is approximately 8 quarters. The implication of this result is that the CFA franc can still be further devalued.

Table 4: Regime Transition Probability and Expected Duration

\begin{tabular}{ccc}
\hline & \multicolumn{2}{c}{ Constant Transition Probabilities: } \\
& $\mathrm{P}(\mathrm{i}, \mathrm{k})=\mathrm{P}(\mathrm{s}(\mathrm{t})=\mathrm{k} \mid \mathrm{s}(\mathrm{t}-1)=\mathrm{i}),($ row $=\mathrm{I} /$ column $=\mathrm{j})$ \\
\hline & 1 & 2 \\
1 & 0.68590 & 0.31410 \\
2 & 0.11980 & 0.88020 \\
\multicolumn{4}{c}{ Constant Expected Duration } \\
& 1 & 2 \\
& 3.18990 & 8.35050 \\
\hline
\end{tabular}

The graph below shows the smooth probabilities of exchange rate behaviour within the two regimes.

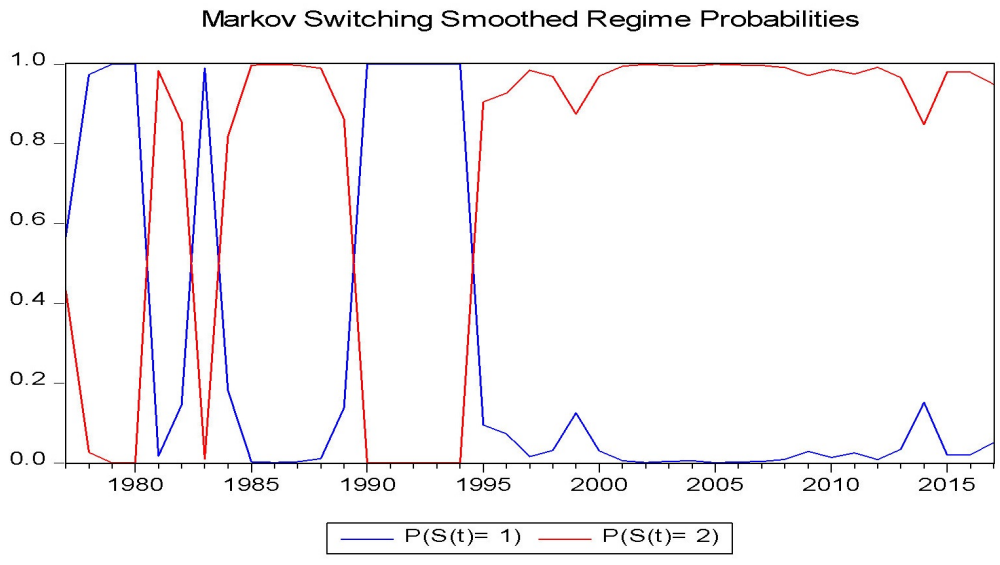

Figure 4: Smooth Regime Probabilities 


\subsection{Conclusion}

Recently, regime-switching models have been used to analyse the behaviour of non-linear macroeconomic variables. The CFA franc has undergone two exchange rate regimes which underscore the use of the Markov-Switching process to analyse its behaviour. The findings reveal that the expected duration for the currency to be undervalued is twice higher than for it to be overvalued, implying that there is a high probability that the CFA franc will further be devalued. This is possible because the CFA is prone to a contagion effect since it is currently being pegged to the Euro and can possibly be devalued in the wake of a Euro crisis. Though the level of growth increased significantly during the undervaluation era, the level of uncertainty remains equally high. Lastly, the results confirm the researchers conjecture that, exchange rate devaluation influences private agents' expectations which in turn trigger an attack on the domestic currency thereby, suppressing its value. Hence the CFA franc is prone to both speculative attacks and a contagion effect.

These findings suggest that policy makers need to implement sound macroeconomic policies that will make them to continually attain their primary goals (sustainable growth and price stability) also, the imperative for a strong financial system that will readily provide substantial capital for investment activities in the country.This joint effort can make the economy less vulnerable to external shocks thereby, reducing the contagion effect. Again, Cameroon needs consistent fiscal and monetary policies that can restore investors' confidence. This will reduce speculative attacks on the domestic currency, thus, reducing the rate of capital outflow from the economy.

\section{References}

Abdih, Y., \& Tsangarides, C. (2010). FEER for the CFA franc, Applied Economics, 42, 2009-2029.

Abiad, A. (2003). Early-Warning System: A Survey and a regime-switching approach. IMF Working Paper WP/03/32. 
Agbohou, N. (2008). Le Franc CFA et l'Euro contre l'Afrique. Editions Solidarité Mondiale. New introduction by Professor François Ndengwe, introduction by Professor Grégoire Biyogo and prologue by Professor Jean Ziegler.

Agénor P. R. \& Montiel, P. J. (1996). Development Macroeconomics, Princeton University Press, 679.

Ahlers, T. \& Hinkle, L. (1999). Estimating the equilibrium real exchange empirically in Exchange Rate Misalignment: Concepts and Measurement for Developing Countries, (Eds) Hinkle, L., \& Montiel, P., World Bank, Washington, pp. 293-358.

Al-Assaf, G., Al-Tarawneh, A., \& Alawin, M. (2013), Determinants of Currency Crisis in Jordan. A Multinomial Logit Model.European Scientific Journal, 9(34), 354-369.

Ambrose, E. (2007). Dollar tumbles as huge credit crunch looms. The Daily Telegraph. London: Telegraph Media Group Limited. Available Online: https://www.telegraph.co.uk/money/?xml=/money/2007/07/25/ cnusecon125.xml.

Baffes, J., Elbadawi, I., \& O'Connell, S. (1999). Single equation estimation of the equilibrium real exchange ratein Exchange Rate Misalignment: Concepts and Measurement for Developing Countries, (Eds) Hinkle, L., and Montiel, P., World Bank, Washington, pp. 405-466.

Bahmani-Oskooee, M.,\& Rhee, H. (1997). Response of Domestic production to Depreciation in Korea: An Application of Johansen's Cointegration Methodology. International Economic Journal, 11, 103-112.

Bazdrech, S., \& Werner, A. (2005). Regime switching models for the Mexican peso. Journal of International Economics, 65(1), 185-201.

Bollen, B, Gray, S., \& Whaley, R. (2000). Regime switching in foreign exchange rates: Evidence from currency option prices. Journal of Econometrics, 94: 239-276.

Boogaerde, P.,\& Tsangarides, C (2005). Ten Years After the CFA Franc Devaluation: Progress Toward Regional Integration in the WAEMU. IMF Working Paper WP/05/145

Brunetti, C., Scotti, C., Mariano, R \& Tan, A. (2008). Markov Switching GARCH Models of Currency Turmoil in Southeast Asia. Emerging Market Review, 9 (2), 104-128.

Chen, C. (2006). Multiple regime models and exchange rate forecasting. JCIS. Available online: https://www.semanticscholar.org/paper/Multiple-Regime 
-Models-and-Exchange-Rate-Chen/549e633e181d0961bChen/ 549e633e181d0961b75a56b846f180be240cea61

Chen, W. \& Shen, C. (2009). Long Swing in Appreciation and Short Swing in Depreciation. Could they Exist in Asian Foreign Exchange? International Research Journal of Finance and Economics, 23, 128-143.

Cheung, Y.,\& Erlandsson, G. (2004). Exchange Rates and Markov Switching Dynamics. CESifo Working Paper Series 1348.

Chinn, M., \& Meese, R. (1992). Banking on currency forecasts: How predictable is change in money? University of California, Santa Cruz.

Clément, J., Mueiller, J., Cossé, S., \& Dem, J. (1996). Aftermath of the CFA franc devaluation. IMF Occasional Paper No. 138.

Cooper, R. (1971). Currency devaluation in developing countries. in Government and economic Development, ed. R.G. New Haven: Yale UP Countries in the CEMAC Zone. MPRA Paper No. 17053, pp. 1-18.

Dembele D. (2014). 20 years after devaluation: What is the future for the CFA franc? Available Online: http://pambazuka.org/en/category/features/91209.

Devarajan, S. (1997). Real exchange rate misalignment in the CFA zone. Journal of African Economies, 6(1), 35-53.

Devarajan. S., \& Hinkle, L. (1994). The CFA Franc Parity Change: An Opportunity to Restore Growth and Reduce Poverty. Afrika Spectrum, 29(2), $131-51$

Diaz-Alejandro, C. (1963). A Note on the Impact of Devaluation and the Redistributive Effects. Journal of Political Economy, 71, 577-580.

Diebold, F. \& Mariano, R. (1991). Comparing predictive accuracy I: an asymptotic test. Discussion Paper / Institute for Empirical Macroeconomics 52, Federal Reserve Bank of Minneapolis.

Diebold, F. \& Nason, J.(1990). Nonparametric exchange rate prediction.Journal of International Economic, 28, 315-332.

Dornbusch, R., Yung, P., \& Stijn, C. (2000). Contagion: Understanding How it Works. The World Bank Research Observer, 15 (2), 177-197.

Drabek, Z., \& Brada, J. (1998) Exchange Rate Regimes and the Stability of Trade Policy in Transition Economies. World Trade Organization Staff Working Paper, 98(07), pp. 1-34.

Elliott, G., Rothenberg, T., \& Stock, J.(1996). Efficient tests for an autoregressive unit root. Econometrica, 64, 813-836. 
Engel, C. (1992). Can the Markov switching model forecast exchange rates? Journal of International Economics, 36, 151-165.

Engel, C., \& Hamilton, J. (1990). Long swings in the dollar: Are they in the data and doFederal Reserve Bank of Minneapolis, Discussion Paper no. 52.

Engel, C. (1994). Can the Markov switching model forecast exchange rates. Journal of International Economics, 151-165.

EViews 9. (2015). User's Guide II Copyright (C) 1994-2015 IHS Global Inc. http://schwert.ssb.rochester.edu/a425/EV92.pdf

Flood, R., \& Garber, P. (1984). Collapsing Exchange-Rate Regimes: Some Linear Examples. Journal of International Economics, 17, 1-13.

Forgha, N. (2008). Capital Flight, Measurability and Economic Growth in Cameroon: An Econometric Investigation. International Review of Business Research Papers, 4(2), 74-90.

Fratzscher, M. (1998). Why are Currency Crises Contagious? A Comparison of the Latin American Crisis of 1994-1995 and the Asian Crisis of 1997-1998. Review of World Economics, 134, 664-691.

Fratzscher, M. (1999). What Causes Currency Crises: Sunspots, Contagion or Fundamentals? EUI Working Papers 99/39, European University Institute.

Gnansounou, S., \&Verdier-Chouchane A.(2012).Misalignment of the Real Effective Exchange Rate: When Should the Franc CFA be Devalued Again? Working Paper Series No 166, African Develoment Bank Group.

Goldfeld, S., \& Quandt, R. (1973). A Markov model for switching regressions. Journal of Econometrics, 1, 3-16.

Gray, S. (1996). Modeling the conditional distribution of interest rates as a regime switching Process. Journal of Financial Economics, 42(1), 27-62.

Hamilton, J. (1989). A new approach to the economic analysis of nonstationary time series and the business cycle. Econometrica, 57, 357-384.

Helleiner, E. (2011). Understanding the 2007-08 Global Financial Crisis: Lessons for Scholars of International Political Economy. Annu. Rev. Political Sci, $14(1), 67-87$.

Goutte, S., \& Zou, B. (2011). Foreign exchange rates under Markov Regime switching model. https://hal.archives-ouvertes.fr/hal-00643900v1.

Hamilton, J., \& Susmel, R. (1994). Autoregressive conditional heteroskedasticity and changes in regime. Journal of Econometrics, 1(64), 307-333. 
Hellwig, C. Mukherjee, A., \& Tsyvinski, A. (2006). Self-Fulfilling Currency Crises: The Role of Interest Rates, American Economic Review, 96(5), 17691787.

Heriqbaldi, U. (2009). Exchange Market Pressure In Indonesia: A Univariate Markov Switching Analysis. Asian Economic and Financial Review, 2(5), 603-616.

Huang, H., \& Malhotra, P. (2004) Exchange Rate Regimes and Economic Growth: Evidence from Developing Asian and Advanced European Economies. Available Online:http://www.cgu.edu/include/Huang.pdf.

Kamin, S., \& Rogers, J. (1997). Output and the Real Exchange Rate in Developing Countries: An Application to Mexico Board of Governors of the Federal Reserve System (U.S.). International Finance Discussion Papers: 580.

Kiguel, M., \& Ghei, N. (1993). Bank Policy Research Working Paper 1224, World Bank, Washington. DC.

Kim, C., \& Nelson, C. (1999). State Space Models with Regime Switching, Classical and Gibbs Sampling Approaches with Applications, Cambridge, MA: MIT Press.

Krugman, P. (1979). A model of balance-of-payments crises. Journal of Money, Credit, and Banking, 11, 311-325.

Labonte, M. (2004). Fixed Exchange Rates, Floating Exchange Rates, and Currency Boards: What Have We Learned? CRS Report for Congress. 1-24.

Lee, Y., \& Chen, L. (2006). Why use Markov-switching models in exchange rate prediction? Economic Modelling, 23(4), 662-668.

Lendjoungou, F. (2009). Competitiveness and the real exchange rate: the standpoint of countries in the CEMAC zone. MPRA Paper17053, University Library of Munich, Germany.

Linjouom, M. (2004). Estimation du taux de change réel d'équilibre et choix d'un régime de change pour le Cameroun.Cahiers de recherche No. 2004-03, Eurisco, Université Paris Dauphine.

Markov, A. (1908). Extension of Limit Theorems of the Calculus of Probabilities to Sums of Quantities Associated into a Chain (in Russian), Zapiski Akad. Nauk (St. Petersburg), Fiz.-Mat. Otd., (7th Ser.).22 (9), 363-397.

Martinez, S., \& Peria, S. (2002). A Regime Switching Approach to Studying Speculative Attacks: A Focus on EMS Crises. Empirical Economics, 27 (2), 299-334. 
Meese, R., \& Rogoff, K. (1983). Empirical exchange rate models of the seventies: Do they fit out of sample? Journal of International Economics, 3-24.

Morley, S. (1992). On the Effect of devaluation during Stabilization Programs in LDCs. The review of Economics and Statistics, 74(1), 21- 27.

Morris, S., \& Shin, H. (1998). Unique Equilibrium in a Model of Self-Fulfilling Currency Attacks.American Economic Review, 88(3), 587-597.

Nikolsko-Rzhevesky, A., \& Prodan, R. (2014). Markov switching and exchange rate predictablity. International Journal of Forecasting, 353-365.

Norris, F. ( 2008). United Panic. The New York Times Available Online: https://economix.blogs.nytimes.com//2008/10/24/united-panic

Obstfeld, M. (1986). Rational and Self-Fulfilling Balance-of-Payments Crises. American Economic Review, 76, 72-81.

Obstfeld, M. (1996). Models of Currency Crises with Self-Fulfilling Features. European Economic Review, 40, 1037-47.

Osadume, R., \& Mbachu, A. (2017). Impact of Global Financial Crisis on Nigerian Economy (2000 -2015). International Journal of Economics and Financial Management, 2 (1), 1-19.

Petreski, M. (2005). The Reverse Relationship between the Choice of Exchange Rate Regime and the Macro-variables. SSRN Economic library, 1-8.

Quandt, R. (1958). Estimation of the Parameters of a Linear Regression System Obeying Two Separate Regime. Journal of The American Statistical Association, 53, 873-880.

Salant, S., \& Dale, H. (1978). Market anticipations of government policies and the price of gold. Journal of Political Economy, 86, 627-48

Shafiquddin, R. (2016). A Markov-Switching Model of Taka/Rupee Exchange Rate:Estimationand Forecasting. Unpublished Masters Thesis, Department of Economics, East West University Bangladesh.

Sosa, M., \& Ortiz, E. (2016). Global Financial Crisis Volatility Impact and Contagion Effect on NAFTA Equity Markets. Estocastica, 7 (1), 67-88.

Tasassa C., Yamb B.., \& Kouezo, B. (2002). The misalignments of real exchange rates in the franc zone countries: An empirical analysis. African Economic Consortium AERC/CREA. Biannual Research Workshop, Nairobi, Kenya.

Tembe, A., Tawa, N. (2017). The determinants of trade in the Central African Economic and Monetary Union R 121177, Research in Business and Economics Journal, 1-15. 
Tsaur, R. (2012). A Fuzzy Time Series-Markov Chain Model with an Application to Forecast the Exchange Rate between the Taiwan and Us Dollar. International Journal of Innovative Computing, Information and Control, 8(7), 4931- 4942.

Vargas, G. (2009). Markov switching VAR model of speculative pressure: an application to the Asian financial crisis. Dissertations and Theses Collection (Open Access). http://ink.library.smu.edu.sg/etd_coll/27.

Yarmohammadi, M., Mostafaei, M., \& Safaei, M. (20012). Markov Switching Models for Time Series Data with Dramatic Jumps. Sains Malaysiana, 41(13), 371-377. 